\title{
Teshuva: A Look at Repentance, Forgiveness and Atonement in Jewish Law and Philosophy and American Legal Thought
}

Samuel J. Levine

Touro Law Center

Follow this and additional works at: https://digitalcommons.tourolaw.edu/scholarlyworks

Part of the Other Law Commons

\section{Recommended Citation}

27 Fordham Urb. L. J. 1677 (1999-2000)

This Article is brought to you for free and open access by the Faculty Scholarship at Digital Commons @ Touro Law Center. It has been accepted for inclusion in Scholarly Works by an authorized administrator of Digital Commons @ Touro Law Center. For more information, please contact Iross@tourolaw.edu. 


\title{
TESHUVA: A LOOK AT REPENTANCE, FORGIVENESS AND ATONEMENT IN JEWISH LAW AND PHILOSOPHY AND AMERICAN LEGAL THOUGHT
}

\author{
Samuel J. Levine*
}

\section{INTRODUCTION}

In his contribution to a recent UCLA Law Review symposium, ${ }^{1}$ Professor Stephen Garvey introduces and develops the possibility of viewing "punishment as atonement." Garvey describes an "ideal community" in which punishment serves as "a form of secular penance aimed at the expiation of the wrongdoer's guilt and his reconciliation with the victim and the community." 3 Recognizing that the concept of atonement "sounds religious," Garvey insists and sets out to demonstrate that "atonement makes perfectly good sense independent of religion." ${ }^{4}$ Nevertheless, Garvey acknowledges that "religion is one place where you'll find atonement's roots" and identifies St. Anselm's eleventh century work as an early example of a theological discussion of atonement. ${ }^{5}$ In further discussions of "theological atonement," Garvey cites not only

* Law Clerk to the Honorable David N. Edelstein, United States District Court for the Southern District of New York; former Assistant Legal Writing Professor \& Lecturer in Jewish Law, St. John's University School of Law; LL.M. 1996, Columbia University; Ordination 1996, Yeshiva University; J.D. 1994, Fordham University; B.A. 1990, Yeshiva University.

Unless otherwise noted, all translations of Hebrew were made by the author. As a result, the Fordham Urban Law Journal takes no responsibility for the author's interpretation of Hebrew materials and the propositions those works support.

This Essay was submitted in connection with the Symposium, The Role of Forgiveness in the Law, held at Fordham University School of Law on January 28, 2000. I thank the editors of the Fordham Urban Law Journal for their interest in the subject of the Essay and Fraida Liba and Yehudah Tzvi for their encouragement.

1. See Symposium, The Future of Punishment, 46 UCLA L. REv. 1719 (1999). (1999).

2. See Stephen P. Garvey, Punishment as Atonement, 46 UCLA L. REv. 1801

3. See id. at 1802. A similar approach has been proposed by a federal judge who "hypothesize[s] that in certain cases it would be beneficial to society if ... we were to permit certain of them who are sincerely sorry to repent, atone for their crimes, and to seek, with the potential for earning, an official forgiveness - a 'fresh start." Richard Lowell Nygaard, On the Role of Forgiveness in Criminal Sentencing, 27 SETON Hall L. Rev. 980, 983 (1997).

4. Garvey, supra note 2, at 1803.

5. Id. at 1802-03 (citing St. Anselm, Cur Deus Homo, in Saint Anselm: BaSiC WRITINGS 171 (S.N. Deane trans., 2d ed. 1962)). 
Christian sources but also, briefly, Jewish sources, which he traces to the biblical book of Leviticus. ${ }^{6}$

Garvey posits that his analysis of theological atonement "shed[s] some light on the problem of punishment in our secular world."7 According to Garvey, parallel to theological accounts of atonement, which "depend critically on treating God as the object of the sinner's identification," a secular account of atonement "take[s] the object of identification not to be God, but one's community and its members." 8 Thus, having largely dispensed with the need to distinguish, for analytical purposes, between theological and secular approaches, Garvey relies on sources based in various forms of moral philosophy to develop an extensive description of the "process of atonement."

The aim of this Essay is to carry forward Professor Garvey's project through a more detailed exploration of the concept of teshuva ${ }^{10}$ in Jewish law and philosophy. The principle of teshuva is

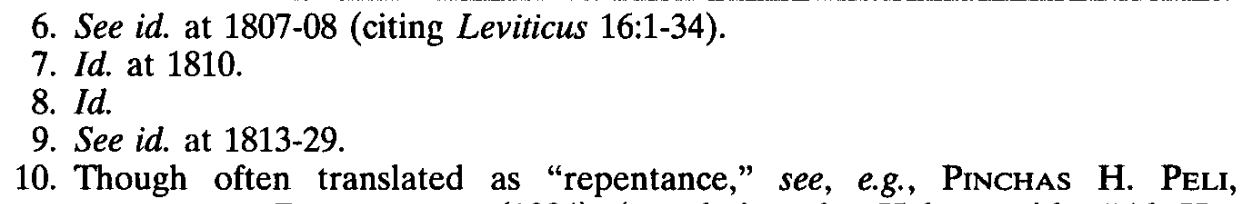
SolovertchiK on Repentance (1984) (translating the Hebrew title "Al Hateshuva"), the Hebrew term "teshuva" is a derivation of the Hebrew root for returning, highlighting the purpose and dynamics of teshuva. Teshuva affords humans a process through which they are able to renounce and repair the improper actions that have led them astray, returning to God and to their own true selves by following the path that God has set down. Cf. Garvey, supra note 2, at 1816 (writing that an apology "distances and disassociates the true self from the guilt-tainted self"); MAIMONIDES, Mishne TORAH [CODE OF LAw], Laws of Teshuva 2:4 (documenting the practice of changing one's name after undergoing the process of teshuva, to demonstrate that "I am someone else, not the person who committed the wrongful act").

Indeed, a number of foundational biblical verses describing the imperative for atonement speak of "returning" to God. See, e.g., Deuteronomy 4:30, 30:2, 30:10; Hosea 14:2. This verse from Hosea, which begins with the Hebrew word "shuva," or "return," opens a section from the writings of the Hebrew prophets that is read publicly on the Sabbath during the period of teshuva, observed between the holidays of Rosh Hashana and Yom Kippur. This Sabbath is commonly known, alternately, as either the Sabbath of "shuva" or the Sabbath of "teshuva." That these terms are used interchangeably to label this Sabbath further demonstrates that these words not only share a common root, but, in the context of atonement, also connote a very similar concept.

As Rabbi Joseph Soloveitchik explained, although a human cannot actually harm God, the commission of a wrongdoing creates a distance between a person and God. See Peli, supra, at 85 (citing MAImonides, supra, Laws of Teshuva 7:7 (quoting Isaiah 59:2)). Maimonides movingly describes the transformative power of teshuva, through which the person who "yesterday was distant from God ... today clings to God." See MAIMONIDES, supra, Laws of Teshuva 7:7. It is through teshuva, then, that the individual can both "return" to God and "return" to the self who does not carry the burden of sin. 
fundamental to Jewish law and philosophy. ${ }^{11}$ Jewish law views it as apparent that human beings are, by their very nature, fallible and incapable of avoiding all $\sin ,{ }^{12}$ and thus through the possibility indeed the obligation ${ }^{13}$ - of teshuva, God provides humans a means of achieving atonement for wrongdoings. ${ }^{14}$

The complete process of teshuva thus involves not only repentance and remorse, but a more complete achievement of forgiveness and atonement. For the purposes of this comparative study, the more limited concept of charata - or remorse - is equated with Garvey's use of the term "repentance," compare MAIMONIDEs, supra, Laws of Teshuva 2:2, with Garvey, supra note 2, at 1814, while teshuva is used to refer to the broader process of atonement. $C f$. Adin Steinsaltz, Teshuvah 3 (Michael Swirsky ed. \& trans., 1996).

Broadly defined, teshuva is more than just repentance from sin; it is a spiritual reawakening, a desire to strengthen the connection between oneself and the sacred .... [A]t the root of the notion of teshuva lies the concept of return (shivah) - return, not only to the past ... but to the Divine source of all being.

Id. See also Nygaard, supra note 3, at 985 n.17 (stating that "metanoia," though "[u]sually translated as 'repentance,' ... actually means something richer [,] closer to 'whole change' or 'new state' of mind, indicating a wholly new direction").

The word "teshuva," transliterated from the Hebrew, appears in English works in a variety of other forms as well, including teshuvah, t'shuvah and t'shuva. In the interest of consistency, I have altered the spelling in some quotations to conform with a uniform transliteration of "teshuva." In the interest of faithfulness to the original works, however, I have not altered the spellings of the titles of the works cited.

11. See Sternsaltz, supra note 10, at 3 ("Teshuva occupies a central place in Judaism ..."). See also generally 2 ARyeh Kaplan, The Handbook of Jewish Thought ch. 15 (Abraham Sutton ed., 1992).

12. See 1 Kings 8:46; Ecclesiastes 7:20; Psalms 103:3. For a discussion of moral vulnerability and susceptibility to temptations of evil in the human condition, see Abraham R. Besdin, Reflections of the Rav: Lessons In Jewish Thought 4450 (1979) (adapted from lectures of Rabbi Joseph B. Soloveitchik). Cf. Garvey supra note 2, at 1811' (quoting P.S. Greenspan, Practical Guilt: Moral Dilemmas, EMOTIONS, AND SOCIAL NORMs 133 (1995)) (describing a "morality built on a view of human nature as imperfect but improvable").

13. For discussions of whether teshuva is considered a Biblical commandment and of its precise mode of performance, see KAPLAN, supra note 11, at 205 n.5; PELI, supra note 10 , at $67-76$.

Even if teshuva is not technically counted as one of the 613 commandments enumerated in the Torah, it is clearly an obligation incumbent upon an individual who sins. See Peli, supra. For a discussion of the concept, identification and derivation of unenumerated Biblical obligations, see Samuel J. Levine, Unenumerated Constitutional Rights and Unenumerated Biblical Obligations: A Preliminary Study in Comparative Hermeneutics, 15 Const. COMM. 511 (1998).

14. See, e.g., Deuteronomy 30:2-3; Isaiah 1:18;43:25, 44:22. See also StEINSALTZ, supra note 10, at 3-4 ("All forms of teshuva, however diverse and complex, have a common core: the belief that human beings have it in their power to effect inward change.").

The opportunity for teshuva is often portrayed in Jewish thought as a manifestation of Divine beneficence that allows those who have violated God's laws to return to the proper path and atone for wrongdoing. See, e.g., Bachya Ibn Paquda, Duties of the Heart, Introduction to Section 7; Rabbenu Yonah Gerondi, Sha'Arei 
Though the verses in Leviticus cited by Garvey represent an early depiction of the mechanics and purposes of atonement in Jewish law, teshuva has occupied a central place in Jewish thought, from the Bible and the Talmud to the legal and philosophical writings of medieval and modern scholars. ${ }^{15}$ These sources portray a complex process consisting of several steps required of the penitent individual, a process strikingly similar to that which Garvey describes. This Essay looks to further develop some of Garvey's ideas by closely analyzing teshuva, which stands as an illuminating conceptual analog to Garvey's depiction of secular atonement. ${ }^{16}$

Teshuva 1:1; Rabbenu Nissim Gerondi (Ran), Derashot Haran 98-99, 107 (Leon A. Feldman ed., 1973); SreinsalTZ, supra, at 4.

According to the Talmudic sages, this possibility of altering reality after the fact, which is one of the mysteries of all being, was created before the world itself. Before the laws of nature came into existence ... a principle even more fundamental and more exalted was proclaimed: that changeteshuva-is possible.

STEINSALTZ, supra, at 4.

15. For discussions in English of the history, sources, development and methodology of the Jewish legal system, see Irving A. Breitowitz, Between Civil LAw AND Religious Law: The Plight of the Agunah in American Society 307-313 (1993); Menachem Elon, Jewish Law: History, Sources, Principles 228-39, 281 399 (Bernard Auerbach \& Melvin J. Sykes trans., 1994); Menachem Elon, The Legal System of Jewish Law, 17 N.Y.U. J. InT'L L. \& Pol. 221 (1985); David M. Feldman, Birth Control in Jewish law: Marital Relations, Contraception and Abortion 3-18 (1968); Aaron Kirschenbaum, Equity in Jewish Law: Halakhic Perspectives in Law: Formalism and Flexibility in Jewish Civil Law 289-304 (1991); Samuel J. Levine, Jewish Legal Theory and American Constitutional Theory: Some Comparisons and Contrasts, 24 HASTINGs Const. L.Q. 441, 447-77 (1997).

16. A substantial body of literature has developed debating the efficacy of relying on religious sources to analyze and apply secular concepts in the American legal system. See, e.g., Stephen L. Carter, The Culture of Disbelief: How American Law and Politics Trivialize Religious Devotion (1993); Kent Greenawalt, Private Consciences and Public Reasons (1995); Kent Greenawalt, Religious Convictions and Political Choice (1988); Michael J. Perry, Religion in Politics: Constitutional and Moral Perspectives (1997); Michael J. Perry, Love and Power: The Role of Religion and Morality in American Politics (1991); Michael J. Perry, Morality, Politics, and Law: A BicentenNIAL Essay (1988); Suzanna Sherry, Religion and the Public Square: Making Democracy Safe for Religious Minorities, 47 DePaul L. Rev. 499 (1998); Symposium, Law and Morality, 1 Notre Dame J.L. Ethics \& Pub. Pol'y 1 (1984); Symposium, Religion and the Judicial Process: Legal, Ethical, and Empirical Dimensions, 81 MARQ. L. REv. 177 (1998); Symposium, The Role of Religion in Public Debate in a Liberal Society, 30 San Diego L. Rev. 849 (1993); Ruti Teitel, $A$ Critique of Religion as Politics in the Public Sphere, 78 Cornell L. Rev. 747 (1993).

A less extensive but similar debate has focused on the application of Jewish legal theory to American law. Compare Samuel J. Levine, Capital Punishment in Jewish Law and its Application to the American Legal System, 29 St. MARY's L.J. 1037, 1037$38 \mathrm{n} .2$ (1998) (citing, as examples of scholarship endorsing such application, David R. Dow, Constitutional Midrash: The Rabbis' Solution to Professor Bickel's Problem, 29 Hous. L. Rev. 543, 544 (1992); Irene Merker Rosenberg \& Yale M. Rosenberg, Guilt: 


\section{The Process of Atonement: A Comparative Analysis}

The process of atonement that Garvey proposes places separate obligations on the wrongdoer and the victim. The initial burden, understandably, falls on the wrongdoer, who must engage in "expiation," 17 a moral journey consisting of the four steps of "repentance, apology, reparation and penance." 18 After the wrongdoer

Henry Friendly Meets the MaHaRal of Prague, 90 Mrch. L. Rev. 604, 614-19 (1991)), with id. at $1038 \mathrm{n.3}$ (citing, as examples of scholarship expressing a more cautious approach, Steven F. Friedell, Book Review: Aaron Kirschenbaum on Equity in Jewish Law, 1993 BYU L. Rev. 909, 919 (1993); Suzanne Last Stone, In Pursuit of the Counter-Text: The Turn to the Jewish Model in Contemporary American Legal Theory, 106 HaRv. L. Rev. 813, 893-94 (1993)).

Regardless of the different stances taken in these debates, the application of Jewish law appears appropriate here, given Garvey's own acknowledgment of religion and Jewish law as early sources for the concept of atonement, see supra text accompanying notes 5-6, as well as Garvey's willingness largely to dispense with distinctions between the secular and the religious in discussing the process of atonement. See supra text accompanying notes 7-9.

17. See Garvey, supra note 2, at 1813.

18. Id. Before describing the steps that comprise the process of secular atonement, Garvey establishes that, as a prerequisite to undertaking the process, a wrongdoer must first experience "guilt." See id. at 1810. A person who commits a wrong, according to Garvey, "acquires guilt" or "becomes tainted." Id. Indeed, he writes, "feeling guilt is the appropriate-the virtuous or morally decent-response to one's wrongdoing." Id. at 1810-11. It is the sense of "being 'tainted,' or more ominously 'disfigured' or 'polluted,' " $i d$. at 1810, that, ideally, leads to engagement in the path of atonement as a means of removing the taint. See id. at 1810-13.

For discussions of the importance of feeling guilt or shame in order to facilitate teshuva, see, e.g., Ezekiel 18:61-63; Ezra 9:6; RABBENU YONAH GeRONDI, supra note 14 , ch. 1, at 21-22.

It should be noted that one of the caveats inherent to a comparative study of legal systems composed in different languages involves inevitable ambiguities in syntax. See supra note 10, discussing the translation of "teshuva." Thus, for example, while Garvey emphasizes a distinction between "guilt," which he sees as a positive reaction to wrongdoing, and "shame," which he sees as unproductive and unlikely to result in atonement, see Garvey, supra, at 1811-13, the Hebrew terms for these concepts carry no such contrasting connotations. Indeed, one contemporary scholar of Jewish law, relying on Hebrew primary sources but writing in English, expresses concerns similar to those of Garvey despite using terminology that would appear to contradict Garvey's assertions. According to Rabbi Aryeh Kaplan, one who repents "should experience deep shame" but "should not sink into depression ... knowing how ready God is to forgive ...." See KaPLAN, supra note 11, ch. 15, at 18-19. Cf. Steinsaltz, supra note 10 , at 6.

[G]enuine regret for one's misdeeds and recognition of one's failings do not necessarily lead to the desired outcome ... instead, they can cause a deepening sense of despair and a fatalistic resignation. Rather than promoting positive changes, such despondency, regarded in our tradition as one of the most serious afflictions of the soul, can cause one to sink even further.

Thus remorse ... must be accompanied by something else: belief in the possibility of change. In this sense, the principle of teshuva - that no matter what the starting point ... penitence is possible - is itself and important 
has completed this journey, the victim is then obligated to forgive the wrongdoer, thus completing the process of atonement through a "reconciliation of the wrongdoer and the wronged." 19 This Essay likens Garvey's system of atonement to the process of teshuva, comparing the obligations placed on both parties and the requisite methodology for achieving true atonement.

\section{The Obligations of the Wrongdoer}

In Jewish thought, the process of teshuva ${ }^{20}$ is often described broadly in four stages, similar to Garvey's process. ${ }^{21}$ Although the precise enumeration and identification of these stages varies among scholars, ${ }^{22}$ the general formulation of the process of teshuva contains essentially the same elements listed by Garvey: ${ }^{23}$ remorse, resolution not to repeat the wrongdoing, confession and changing one's ways. ${ }^{24}$ The similarity in the general conceptual frameworks

source of reawakening and hope ... [K]nowing that there is no irredeema-

ble situation [ ] can itself serve as a goad to teshuva.

$I d$. at 6-7. "[W]e focus on our blemishes and faults, not in order to wallow in guilt, but to use our flaws for leverage in the effort to progress .... Evil deeds, once recognized, become a constant goad and encouragement to reform." Id. at 56.

19. Garvey, supra note 2, at 1813.

20. Scholars have emphasized that teshuva is a complex and often difficult process, akin to a spiritual journey. See Peli, supra note 10, at 89 (comparing process of teshuva to a journey along the circumference of a circle, in the course of which it may be difficult to realize that the path ultimately leads to the desired objective); STEINSALTZ, supra note 10, at 7 (comparing one who engages in teshuva to "a person on a journey who at some point decides to change direction" and stating that "the new path, like the one abandoned, is long and arduous").

21. See supra text accompanying notes 17-19.

22. See Steinsaltz, supra note 10 , at 4 .

Many books and articles have been written about teshuva, providing detailed analyses of the various stages of the process form start to finish. Yet, for all this elaboration, a few fundamental principles underlie all forms and levels of teshuva ... . In fact, two essentials are found in every kind of teshuva: the renunciation of a regretted past and the adoption of a better path to be followed henceforth.

Id.

23. Scholars also list these elements in various orders, many of which differ somewhat from the order described by Garvey. For the purposes of this comparative study, Garvey's order has been adopted as a general framework. Indeed, Garvey's own list is a compilation based on the enumerations of different theorists. Compare Garvey, supra note 2, at $1804 \mathrm{n} .4$ (stating that "[a]tonement involves four components - repentance, apology, reparation, and ... penance (though not all of these are always required)" (quoting RichaRd SwinburNe, REsponsibILITY AND ATONEMENT 81 (1989))), with id. (listing "perception of wrongdoing, guilt, and repentance" (quoting James Griffin, Well-Being: Its Meaning, Measurement, and Moral ImPORTANCE 272 (1986))).

24. See Kaplan, supra note 11, at 209; id. at n.37-40. These elements are, indeed, quite similar to those articulated by Garvey. Thus, attention should be paid to the 
of Garvey's process of secular atonement and the process of teshuva may allow for meaningful comparisons and contrasts of the two systems.

\section{A. Repentance}

\section{Garvey relies on a definition of "repentance" as}

the remorseful acceptance of responsibility for one's wrongful and harmful actions, the repudiation of the aspects of one's character that generated the actions, the resolve to do one's best to extirpate those aspects of one's character, and the resolve to atone or make amends for the [wrong and] harm that one has done. ${ }^{25}$

Garvey thus sees repentance as a crucial first step in removing the taint of wrongdoing because it is "active," leading "[t]he repentant self [to] focus[ ] on the wrongdoing that produced the stain in the first place and on what the self can now do about it."26

In Jewish law and philosophy, remorse for a wrong, coupled with the resolution not to repeat the wrongdoing, is likewise essential to any possibility of atonement. In particular, as Maimonides writes in his Code of Law, these elements of repentance are prerequisites to effective confession. ${ }^{27}$ Words of apology that are not accompa-

similarity in substance rather than to the slight difference in terminology, as the terms used for the elements in Jewish thought are translations of the original works. See discussions supra notes $10,18$.

Because the Bible serves as the fundamental source of Jewish law and philosophy, many of the medieval scholars who discuss the process of teshuva cite various Biblical sources for the different stages of teshuva.

For example, verses cited as sources for the step of remorse include Hosea 14:2, cited in Sa'Adia Gaon, Emunoth V'Deoth 5:5; Jeremiah 8:6, cited in Rabbenu YonaH Gerondi, supra note 14, ch. 1, at 10; Jeremiah 31:18, cited in MaIMONIDES, supra note 10, Laws of Teshuva 2:2; Joel 2:14, cited in BACHYA IBN PAQUDA, supra note 14 , ch. 7 , at 4 .

Sources cited for the requirement to resolve not to repeat the wrongdoing include Hosea 14:4, cited in SA'ADIA GAON, supra; Isaiah 55:7, cited in RABBENU YONAH GERONDI, supra, ch. 1, at 11, MAIMONIDES, supra; Job 34:32, cited in BACHYA IBN PAQuda, supra.

Confession is included as part of the process of teshuva in such Biblical sources as Hosea 14:3, cited in SA'ADIA GAON, supra; Leviticus 5:5, cited in RABBENU YoNAH Gerondi, supra, ch. 1, at 40; Numbers 5:6-7, cited in MAIMONIDEs, supra, 1:1; Proverbs 28:13, cited in BACHYA IBN PAQUDA, supra.

Finally, the need to change one's ways is derived from such sources as Hosea 14:2, cited in SA'Adia GaON, supra; Isaiah 55:7, cited in RabBenu YonaH Gerond, supra, ch. 1, at 11, MAIMONIDEs, supra, 2:2, BACHYA IBN PAQUDA, supra.

25. Garvey, supra note 2, at 1814 (quoting Jeffrie G. Murphy, Repentance, Punishment, and Mercy, in Repentance: A Comparative Perspective 143, 147 (1997)).

26. Id. at 1815.

27. See MAimonides, supra note 10, Laws of Teshuva 2:3. 
nied by sincere feelings of regret and resolve to change remain empty, bereft of the crucial element that lends them meaning. ${ }^{28}$

Citing a powerful analogy from the Talmud, Maimonides emphasizes the futility of an attempted confession that lacks the proper intent. ${ }^{29}$ The analogy compares such a confession to an immersion for ritual purity undertaken while the impure individual continues to grasp onto the very object that rendered the individual ritually impure. ${ }^{30}$ Just as it is impossible for ritual purification to take effect until the individual casts away the impure object, it is inconceivable that the purifying effects of confession will set in before the improper acts have been cast aside through regret and resolve for the future. ${ }^{31}$

In addition to its value as an illustration of some of the underlying principles of teshuva, the analogy to the laws of ritual purity underlines the legal nature of teshuva in Jewish thought. Indeed, since the times of Maimonides, scholars of Jewish law have used Maimonides' Laws of Teshuva, incorporated as a section in his Code of Law, as a springboard for extensive legal discussions of the concept of teshuva. ${ }^{32}$ Among the works of contemporary scholars, Rabbi Joseph B. Soloveitchik's discourses are perhaps the most notable example of careful and technical legal analysis of teshuva through an exposition on Maimonides' Code of Law. ${ }^{33}$

Rabbi Soloveitchik posits that according to Maimonides, the role of resolve for the future in the process of teshuva depends on the specific nature of the individual's teshuva. Rabbi Soloveitchik observes that, in Chapter 1 of Laws of Teshuva, Maimonides lists re-

28. Cf. Matthew Atkinson, Red Tape: How American Laws Ensnare Native American Lands, Resources, and People, 23 OKLA. CiTy U. L. Rev. 379, 381 (1998) ("It's difficult to take seriously an apology that is not coupled with atonement." (citation omitted)); Jonathan R. Cohen, Advising Clients to Apologize, 72 S. CAL. L. Rev. 1009,1017 (1999) ("For an apology to comfort the injured party, it must be sincere, or at least perceived to be sincere .... [W]hen an apology is given too cavalierly, the listener may question its meaning."); Deborah L. Levi, Note, The Role of Apology in Mediation, 72 N.Y.U. L. REV. 1165, 1177-78 (1997) ("Like other important rituals, an apology is worthless unless the required gestures are filled with meaning. Apologies are speech-acts ....").

29. See Maimonides, supra note 10, Laws of Teshuva 2:3 (citing TAlmud Bavl, Ta'anith 16a).

30. See id.

31. Cf. Swinburne, supra note 23 , at 82 , cited in Garvey, supra note 2, at 1814 n.47 ("Repentance also involves a resolve to amend - you cannot repent of a past act if you intend to do a similar act at the next available opportunity.").

32. See, e.g., PELI, supra note 10.

33. A portion of these discourses have been collected in PeLI, supra note 10. 
morse prior to resolution for the future, while in Chapter 2, the order of these two elements is reversed..$^{34}$

Asserting that there is no contradiction between the two descriptions, Rabbi Soloveitchik instead suggests that in Chapter 1, Maimonides refers to teshuva that is motivated by emotion, resulting from the wrongdoer's spontaneous inner feelings of shame, which instinctively lead to remorse..$^{35}$ In such a scenario, he explains, it is the individual's sense of utter remorse that automatically brings about the resolve never to commit the same wrongs. ${ }^{36}$ Chapter 2, according to Rabbi Soloveitchik, describes an individual who has arrived at teshuva on an intellectual level, who understands the impropriety and negative effects of sinful behavior and therefore resolves not to engage in such behavior in the future. ${ }^{37}$ In such a case, the individual does not immediately experience passionate feelings of remorse; rather, remorse will grow out of the individual's continued determination not to repeat the wrongful actions in the future. ${ }^{38}$

Thus, the first step in both Garvey's process of atonement repentance - and in the path of teshuva - remorse and resolution not to repeat the wrongdoing - incorporate elements of emotional commitment and future resolve, which must be met before continuing on the road to atonement.

\section{B. Apology}

The next stage Garvey sees in the process of atonement, "confession," serves as "the wrongdoer's public expression of his repentance, whereby he openly acknowledges his wrongdoing and simultaneously disowns it." ${ }^{39}$ Alluding again to the theological roots of the concept of atonement, Garvey refers to an apology as a "secular ritual of expiation." 40 Such expiation is achieved through

34. See id. at 188 (citing Maimonides, supra note 10, Laws of Teshuva 1:1, 2:2).

35. See id. at 200.

36. See id. at 200-01.

37. See id. at 202-03.

38. See id. at 204; $c$. Steinsaltz, supra note 10 , at 5 .

The recognition of the need [for teshuva] comes about in different ways. Sometimes ore is overcome by a sense of sinfulness, of blemish, of defilement, which resulted in a powerful desire for escape and purification. But the desire [for teshuva] can also take more subtle forms, feelings of imperfecId. tion or unrealized potential, which spur a search for something better.

39. Garvey, supra note 2, at 1815 .

40. Id. (quoting Nicholas Tavuchis, Mea Culpa: A Sociology of Apology AND ReCONCILIATION at viii (1991)). 
the profound willingness of the self to "accept[ ] responsibility for its wrongdoing but at the same time disavow[ ] the wrong." ${ }^{11}$ In short, an apology "embraces" guilt and then "expels" it. ${ }^{42}$

Vidui - confession, or apology - likewise serves an indispensable function in the process of teshuva. Through vidui, the individual unequivocally accepts responsibility for wrongdoing, at the same time displaying an outward expression of remorse and a willingness to make amends for the wrong. ${ }^{43}$ Maimonides delineates the essential elements of vidui, which include: language demonstrating a clear admission of having committed a wrong against another; precise articulation of the wrong; a statement of strong remorse; and a declaration of a desire not to repeat the wrong. ${ }^{44}$

In his more detailed description of vidui, Maimonides, who is known for precision and economy of language, ${ }^{45}$ repeatedly emphasizes the importance of verbalizing the feelings of remorse and resolve. ${ }^{46}$ In addition, Maimonides cites Talmudic sources that praise an individual who recites an extended form of vidui by expanding on the more basic elements of confession and apology. ${ }^{47}$

Building on Maimonides' discussions, Rabbi Soloveitchik offers an important psychological insight to explain the power and signifi-

41. Id. at 1816 .

42. Id.

43. Through an analogy to medical ailments, the medieval legal authority Rabbenu Nissim Gerondi (Ran) illustrates the significance of open admission of wrongdoing in the process of teshuva. Ran observes that a doctor cannot heal an individual suffering from a physical malady unless the patient reveals the illness fully to the doctor. Similarly, to be healed of the spiritual ailments that accompany wrongful acts, an individual must acknowledge and identify the wrongdoing, to the self and to God, so that the process of teshuva can begin. See RAN, supra note 14, at 149-50 (citing Hosea 7:1). See also RabBenu Yonah Gerond, supra note 14, ch. 2, at 8 (employing a similar analogy).

Fundamental sources of Jewish law and philosophy have often used an analogy to physical health to help illuminate the notion of the spiritual ailments connected to wrongdoing and, conversely, the healing that accompanies teshuva. See, e.g., BACHYA IBn PAQuda, supra note 14, ch. 7, at 1 (citing Jeremiah 31:29); MAIMONIDEs, supra note 10, Laws of De'oth, chs. 2, 4; MAIMONIDES, INTRODUCTION TO COMMENTARY ON The Mishna, Introduction to Pirke Avoth; Peli, supra note 10, at 146-50 (citing Psalms 103:2-4; Isaiah 6:10; 57:19); RABBENU YonAH GeRONDI, supra note 14, ch. 2, at 3 (citing Isaiah 33:24; Psalms 41:5); id. ch. 4, at 1 (citing Isaiah 6:10; Psalms 41:5); RAN, supra note 14, at 99-100; id. at 107 (citing Hosea 14:5; Ezekiel 18:27-28; TALMUD BAVLI, Yoma 86a-86b).

44. See RabbenU Yonah Gerondi, supra note 14, ch. 1, at 1; see also generally KAPLAN, supra note 11, ch. 16.

45. See Isadore Twersky, Introduction to the Code of Maimonides (MishNeh TORAH) 97 (1980).

46. See Maimonides, supra note 10, Laws of Teshuva 1:1, 2:2, 2:9.

47. See id. at 1:1. 
cance of verbal vidui. Rabbi Soloveitchik notes that human nature sometimes leads a person, consciously or otherwise, to refuse to accept the reality of certain unfavorable facts. ${ }^{48}$ Among the mechanisms a person may employ in the attempt to deny an unfortunate reality, he observes, is to avoid verbally expressing the unpleasant truth. $^{49}$ Perhaps one of the most difficult truths that a person must face involves the acknowledgment of having committed a wrongful act. ${ }^{\text {so }}$ Through the verbal expression of vidui, then, rather than continuing to evade responsibility by deluding others and possibly one's self as well, the individual admits to the truth of the wrongdoing, thereby facilitating the process of teshuva. ${ }^{51}$

48. See Peli, supra note 10, at 93.

49. See id.

50. See Chaim Shmulevitz, Sichoth Mussar $74-76$ (1980) (citing numerous sources in Jewish thought describing the tendency of an individual to justify wrongful acts and the importance of overcoming such an inclination). $C f$. TAlmud BAvLI, Avoth ch. 5, at 9 (listing qualities that indicate wisdom, including willingness "to admit error," can be interpreted literally as "to admit truth").

51. See Peli, supra note 10, at 93-96. Cf. Joel Feinberg, Autonomy, Sovereignty, and Privacy: Moral Ideals in the Constitution?, 58 Notre Dame L. Rev. 445, 480 (1983).

Genuine repentance as well as such states as contrition, remorse, the feeling of guilt, and the desire for atonement, all require some sense of continuity with the past and self-identity with an earlier wrongdoer. The essence of these states is the deliberate taking of responsibility for an earlier doing. To deny one's identity with the wrongdoer is to evade or deny responsibility for his crimes, quite another thing form repentance.

Id.; Theresa Klosterman, Note, The Feasibility and Propriety of a Truth Commission in Cambodia: Too Little? Too Late?, 15 ARIz. J. INT'L \& CoMP. L. 833, 838-39 (1998) (stating that, on a societal level, "[d]etermining the truth about human rights violations is crucial" and that "officially sanctioned ... acknowledgment is important because, in many religious and ethical traditions, it is a prerequisite to societal forgiveness and atonement."); Seymour Moskowitz \& Michael J. DeBoer, When Silence Resounds: Clergy and the Requirement to Report Elder Abuse and Neglect, 49 DePaul L. Rev. 1, 67 (1999) ("The 'confession' can be the catalyst for new behavior. In fact, repentance and accountability for the evil in which the penitent participated may ameliorate or end past wrongs."); STEINSALTZ, supra note 10, at 5-6.

The great obstacle in the way of teshuva ... is self-satisfaction .... This great stumbling block has been referred to by one sage as "obtuseness of the heart." Obtuseness of the mind is easily recognized as an impairment of cognitive functioning; that of the heart is more insidious, a condition of blocked moral and emotional awareness. Without this prodding awareness, however slight, without some feeling of inadequacy, no amount of intellectual sagacity can change a person's behavior .... The initial perception and awakening is, in effect, the first and most inclusive "confession." When a vague feeling of discomfort turns to clear recognition that something is wrong, and when that recognition is expressed in words spoken either to oneself, to God, or to another person, the first step in the process of [teshuva] has been taken, the part that relates to one's previous life and character. 
Thus the second stages of both Garvey's process and of teshuva require a public expression and acceptance of the wrongdoer's responsibility for the bad act, and an overt articulation of regret and repudiation of the wrong.

\section{Reparation and penance}

In Garvey's depiction of the process of atonement, it is incumbent upon the wrongdoer, after feeling remorse and, through apology, verbally expressing such feelings, to "make amends." 52 Garvey suggests that most crimes result in both harm and a moral wrong; therefore, according to Garvey, the remedy for a wrongdoing consists of two corresponding actions, reparation and penance. $^{53}$ Because reparation, in the form of restitution or compensation, "makes amends for the harm the wrongdoer does, but not for the wrong he has done," Garvey explains, in addition to making reparations, "the wrongdoer must submit to penance." 54 Thus, Garvey refers to penance as "the final, critical piece of the expiation half of the atonement process." 55

Id.; Scott E. Sundby, The Capital Jury and Absolution: The Intersection of Trial Strategy, Remorse, and the Death Penalty, 83 CoRnell L. Rev. 1557, 1584 (1998) (documenting that a capital defendant's "acceptance of responsibility truly does influence the jury's decision making" and that "a defendant's verbal acknowledgment of his killing would increase the likelihood of receiving a life sentence").

This explanation of the importance of verbal vidui would further appear to be the rationale behind the principle, which Maimonides again cites from the Talmud, that a person should engage in public vidui as an effective step in the process of teshuva. See Maimonides, supra note 10, Laws of Teshuva 2:5.

Criticizing those who view public apologies as merely "shaming penalties," Garvey cautions us not to "forget that the offender is not only being exposed and shamed, he's also making an apology. Indeed, as far as atonement goes, treating an apology as nothing more than a chance to cause shame misses the point." See Garvey, supra note 2 , at 1816 (emphasis in original).

For descriptive and normative discussions of the use of apology in the American law, see, e.g., id.; Cohen, supra note 28; Dan M. Kahan, What Do Alternative Sanctions Mean?, 63 U. CHI. L. Rev. 591 (1996); Steven Keeva, Does Law Mean Never Having to Say You're Sorry?, A.B.A. J., December 1999, at 64; Levi, supra note 28; Hiroshi Wagatsuma \& Arthur Rossett, The Implications of Apology: Law and Culture in Japan and the United States, 20 L. \& Soc'Y REv. 461 (1986).

52. See Garvey, supra note 2, at 1816,1818. Cf. Moskowitz \& DeBoer, supra note 51 , at 67 (emphasizing that "[t]rue repentance does not deal with feeling, but with action-changing one's behavior, reversing direction"); Reverend Katherine Hancock Ragsdale, The Role of Religious Institutions in Responding to the Domestic Violence Crisis, 58 Alb. L. Rev. 1149, 1168 (1995).

53. See Garvey, supra note 2 , at $1816-27$.

54. Id. at 1818.

55. Id. at 1819. 
Garvey defines penance as "a self-imposed punishment, i.e., selfimposed hardship or suffering, which completes the process of expiation and finally rids the wrongdoer of his guilt."56 Penance plays a unique role in Garvey's view of atonement, which "insists that punishment should do more: It should restore the offender to full standing in the community." 57 To explore the potent question of "[h]ow suffering manage[s] to effect this restoration," Garvey mandates the need "to shift perspectives." 58 Specifically, Garvey's approach requires us "to look at punishment not from the victim's perspective, but from the wrongdoer's."59 This simple yet profound suggestion recognizes that often a wrongdoer "will feel smaller than before" and "will experience anger and resentment toward himself." 60 Significantly, Garvey explains, "the wrongdoer cannot restore his own moral standing unless he submits to punishment." 61

Regarding penance, Rabbi Soloveitchik's discourses on teshuva again provide a helpful complement to Garvey's thoughts. Like Garvey, Rabbi Soloveitchik establishes a framework for analyzing the concept of penance based on the premise that the commission of a wrong results in two interrelated but distinct consequences. He explains that, on one level, in relation to the victim, a wrongful act produces liability on the part of the offender. ${ }^{62}$ Similar to Garvey, Rabbi Soloveitchik posits that to counteract this culpability, the individual must engage in reparation, through the payment of restitution or compensation. ${ }^{63}$ Thus, one kind of teshuva effects kappara, a form of forgiveness or acquittal from wrongdoing. ${ }^{64}$ An individual who undertakes this kind of teshuva both literally and metaphorically pays a debt owed to another and is thereby released from further liability. ${ }^{65}$ Indeed, Rabbi Soloveitchik notes an etymological link that underscores the corresponding conceptual similarity between reparation and this form of forgiveness: kappara derives from the same root as kofer, the Hebrew term for payment of an obligation. ${ }^{66}$

\footnotetext{
56. Id.

57. Id. at 1822.

58. $I d$.

59. Id.

60. Id. at 1823.

61. Id.

62. See Peli, supra note 10, at 49-50.

63. See id. at 50-51.

64. See id. at 51.

65. See id.

66. See id.
} 
Yet, this form of teshuva does not adequately amend for the second result that Rabbi Soloveitchik attributes to the commission of a wrongful act. Employing an approach that anticipates Garvey's, and relying on various sources of Jewish thought, ${ }^{67}$ Rabbi Soloveitchik examines the effect of wrongdoing on the individual who has committed the improper act. Specifically, he acknowledges the spiritual defilement caused by the impurity of $\sin { }^{68}$ To return from such spiritual defilement, Rabbi Soloveitchik explains, the individual must do more than merely pay the victim any obligation arising out of the wrongdoing. ${ }^{69}$ As in Garvey's system, in the final stages of teshuva, Jewish law demands not only reparation, but, more importantly, penance, in the form of fundamental change in the individual's mode of behavior. ${ }^{70}$

To erase fully the taint of the wrongdoing and thus to obtain a restored place in the community, an individual must engage in what Rabbi Soloveitchik terms teshuva of tahara (repentance of purification), a more extensive form of spiritual purification or expiation. ${ }^{71}$ Like penance, teshuva of tahara requires that a person undertake self-imposed forms of hardship, ones that relate to and address directly the particular nature of the act committed. ${ }^{72}$

67. Rabbi Soloveitchik bases his approach on an idea he finds expressed in Biblical sources as well as in both legal and narrative strands of the Talmud, the halacha and the aggada. See id. at 51-55. For a discussion of halacha and aggada in Jewish thought, see Samuel J. Levine, Halacha and Aggada: Translating Robert Cover's "Nomos and Narrative," 1998 UTAH L. REv. 465.

68. See Peli, supra note 10 , at 51 . In addition to its powerful philosophical implications, the notion of a change that takes place in the wrongdoer's personality is expressed in a technical legal sense as well. The Talmud documents Jewish law's acknowledgment of this change in spiritual status through the disqualification as credible witnesses of those individuals who have not reformed from their improper ways. See id. at 55-56 (citing Talmud Bavli, Sanhedrin).

69. Cf. MAIMONIDEs, supra note 10, Laws of Teshuva 1:1 (emphasizing that a person who damages another does not achieve atonement merely through the payment of restitution or compensation).

70. See id. at $2: 2$ to $2: 4$.

71. See Peli, supra note 10 , at 51-52.

72. For example, the Talmud discusses the acts of penance required of a usurer, who, as a result of violating the laws of the Torah, has been disqualified as a credible witness. The Talmud instructs that the usurer must destroy all credit slips and refuse to lend money on interest under any circumstances, even when it may be legally permissible to do so. See Peli, supra note 10, at 56 (quoting Talmud Bavl, Sanhedrin $25 \mathrm{~b}$ ). Thus, teshuva of tahara requires, for the purposes of restoring spiritual purity and the resulting testimonial credibility, acts that demonstrate a renouncement even of the conditions that led to the improper past behavior. See id. Cf. MaImonides, supra note 10, Laws of Teshuva 2:4 (describing such practices as "distancing one's self far from the means of wrongdoing, changing one's name to demonstrate that 'I am not the same who committed those acts,' changing all of one's ways toward the good 
Through teshuva of tahara, then, an individual truly regains and returns to the state of undefiled spirituality lost as a consequence of the wrongdoing. ${ }^{73}$

\section{The Obligations of the Wronged: Reconciliation}

Once the wrongdoer has successfully completed expiation and the guilt has thereby been removed, Garvey writes, it is then time for the victim to complete the process of atonement through forgiveness. ${ }^{74}$ According to Garvey, forgiveness "achieves the reconciliation of wrongdoer and wronged." 75 Specifically, Garvey suggests, just as expiation "enables an offender to purge the taint of guilt," expiation coupled with forgiveness "enables the victim to overcome his resentment."76

Discussing the mechanics of forgiveness, Garvey argues that although

[a] victim may permissibly extend forgiveness to a wrongdoer who has done nothing but repent ... a victim may also legitimately withhold forgiveness until the wrongdoer has paid his debt in full, i.e., until the wrongdoer has not only repented but also apologized, made reparations, and endured his penance. Indeed, forgiveness may take some time in coming. ${ }^{77}$

Ultimately, however, Garvey considers forgiveness "one of th[e victim's] responsibilities."78 Indeed, Garvey finds that "[i]t reflects a moral failure ... for victims to withhold forgiveness unreasonably

and proper path, and exiling one's self"); RABBENU YonAH GeRONDI, supra note 14, ch. 1 , at 35 .

73. See Peli, supra note 10, at 55-56. The medieval scholar Rabbenu Yonah Gerondi elaborates on the biblical analogy of cleaning a stained garment to describe different modes and levels of teshuva and their effectiveness in removing the spiritual taint of wrongful acts. See Rabbenu Yonah Gerondi, supra note 14, ch. 1, at 9 (citing Jeremiah 4:14; Psalms 51:4). Specifically, he points to the difference between a superficial washing of a garment, which may remove dirt, and a more thorough cleaning, which will restore the garment's original color and brightness. See id. Cf. Ran, supra note 14, at 108 (citing TALMUD BAVLI, Yoma 86b) (describing different types of teshuva and corresponding levels of expiation); Steinsaltz, supra note 10, at 53 ("Teshuva has two essential phases: a leap of disengagement from the past, and a lengthier, more arduous process of rectification. The first phase is one of destruction, the second of reconstruction."). See generally KaPLAN, supra note 11, ch. 17.

74. See Garvey, supra note 2, at 1813.

75. See id.

76. See id. at 1828. Cf. Nygaard, supra note 3, at 984 ("Forgiveness looks evil in the eye, condemns it, but still permits one who meets the forgiver's criteria, to start anew.").

77. Garvey, supra note 2, at 1828 (emphasis in original).

78. Id. at 1827 . Cf. Levi, supra note 28, at 1178 (stating that the "effectiveness [of an apology] in reconciliation depends not only on the speaker but also on the partici- 
from offenders who have done all they can do to expiate their guilt."79

A similar approach to the dynamics of forgiveness is found in Jewish thought. Discussing the obligations owed to the victim, Maimonides explains that teshuva in the form of reparations is not sufficient, but that the wrongdoer must repeatedly appease the victim and ask for forgiveness. ${ }^{80}$ The responsibility on the wrongdoer is such that, if the victim initially refuses the request, the wrongdoer must continue to make a number of attempts to obtain forgiveness. ${ }^{81}$

Nevertheless, once the wrongdoer has repeatedly demonstrated a sincere hope for reconciliation, parallel to Garvey's approach, Jewish law places the burden on the victim to grant forgiveness. In the powerful formulation of Maimonides, if the victim continuously denies forgiveness, the wrongdoer is released from further action, as the victim is then deemed to be the sinner ${ }^{82}$ Indeed, Maimonides emphasizes the responsibility incumbent on the victim, writing that it is improper for a person to withhold forgiveness; instead, a victim should be receptive to the wrongdoer's genuine attempts at reconciliation and atonement. ${ }^{83}$

\section{Conclusion}

Despite the prominent position it has held for millennia in religious and moral thinking, the atonement model is relatively new to

pation of an injured party. Absent the eventual complicity of the injured party, the apologizer's words are just talk.").

79. Garvey, supra note 2, at 1828. Cf. Cohen supra note 28, at 1021 (citing psychological evidence finding that "an injured party ... who fails to forgive after receiving an apology [ ] may suffer the corrosive effects of storing anger"); Levi, supra note 26 , at 1178 ("By apologizing, the offender acknowledges her diminutive moral stature and asks for restorative forgiveness. She also acknowledges the existence and importance (to both parties) of the moral register itself. When the apologizee gestures to acknowledge that meaning, he closes the circle of performance, thus establishing a new moral equilibrium."); Nygaard, supra note 3, at 1012.

For the offender who is sincerely repentant; feels shame for his act; who has recaptured compassion for the feelings of others; realizes the pain he has caused; and, who truly desires to turn a new leaf and be reconciled with society; the system must determine how it can facilitate that desire, not frusId.

trate it out of ignorance or misguided notions.

80. See Maimonides, supra note 10, Laws of Teshuva 2:9; Rabbenu Yonah GerONDI, supra note 14, ch. 1, at 44.

81. See Maimonides, supra note 10, Laws of Teshuva 2:9; Rabbenu YonaH GerONDI, supra note 14, ch. 4, at 19.

82. See Maimonides, supra note 10, Laws of Teshuva 2:9.

83. See id. at $2: 10$. 
American legal theory. Professor Garvey's attempt to offer a systematic depiction and analysis of the process of atonement and its possible relevance to American law appears to represent the most extensive such effort to date.

As Garvey himself concedes, any application of a theory of atonement to the American legal system will encounter a number of problems and objections. For example, he acknowledges that "[i]f in the end you remain convinced that the ideal of community on which I base my account of atonement is indeed dangerous or irretrievable, then you will ... be forced to turn elsewhere for your understanding of punishment." 84 These difficulties only increase when the analysis relates the concept of teshuva from Jewish law and philosophy to American law. ${ }^{85}$ Nevertheless, Garvey's attempt is successful, for reasons that would appear to apply to theories of teshuva as well.

First, Garvey emphasizes that his "immediate aim is normative, not practical," and, therefore, "the discussion proceeds at a high level of abstraction" rather than "develop[ing] any concrete proposals for institutional or doctrinal reform." ${ }^{86}$ Second, Garvey explains that a new model is necessary based on his conclusion that "the prevailing models of punishment ... deterrence[,] retributivism[,] restorativism and libertarianism ... fall short." 87 Finally, as Professor David Dolinko noted in introducing the symposium in which Garvey participated, Garvey's proposal offers a fresh perspective at a time when "[c]riminal punishment is an institution that is large, growing, and quite possibly mutating into new and surprising forms." ${ }^{88}$ Ultimately, it is perhaps ironic that, in providing a new theory of punishment for American legal thought to consider in a future millennium, Garvey has in fact looked back to theories of atonement and teshuva that have spanned millennia of the past. The path to teshuva may indeed provide insight in formulating a new perspective on the notions of punishment underlying American law.

84. Garvey, supra note 2, at 1803.

85. Indeed, in the past I have expressed my own doubts about attempts to derive practical lessons for the application of the death penalty in the United States based on the approach to capital punishment in Jewish law, because, "[a]lthough the processes of repentance and atonement are inherent parts of the Jewish legal system, that is clearly not the case in American penal law." See Levine, Capital Punishment, supra note 16, at 1043 \& nn.22-24. See also discussion supra note 16.

86. Garvey, supra note 2, at 1804.

87. Id. at 1829-30.

88. David Dolinko, The Future of Punishment, 46 UCLA L. Rev. 1719, 1726 (1999). 


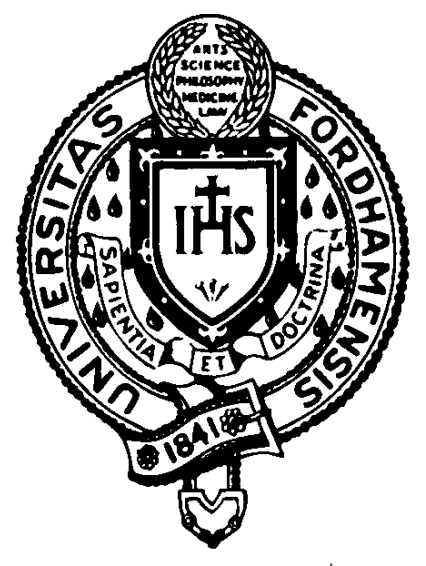

Heinonline -- 27 Fordham Urb. L.J. 1694 1999-2000 